$\begin{array}{ll}\text { Volume } & : 06 \\ \text { Nomor } & : 02 \\ \text { Bulan } & : \text { Mei } \\ \text { Tahun } & : 2020 \\ \text { http } & : / / \text { jurnal.pps.ung.ac.id/index.php/AKSARA/index }\end{array}$

\title{
Pemetaan Sosial Pada Pengrajin Bambu di Desa Parungsari Kabupaten Karawang
}

\author{
Anggi Pasca Arnu, Raden Aditya Kristamtomo Putra, Nanu Hasanuh \\ Fakultas Ekonomi Universitas Singaperbangsa Karawang \\ e-mail: anggi.pasca@fe.unsika.ac.id, raden.aditya@fe.unsika.ac.id, \\ nanu.hasanuh@fe.unsika.ac.id
}

Received: 23 Februari 2020; Revised: 27 April 2020; Accepted: 28 April 2020

DOI: http://dx.doi.org/10.37905/aksara.6.2.151-160.2020

\begin{abstract}
Abstrak
Pemetaan social merupakan kegiatan yang dilaksanakan untuk memahami kondisi sosial masyarakat lokal. Penelitian ini bertujuan untuk mengetahui dan memahami kondisi desa Parungsari, kondisi sosial ekonomi dan sebagai data primer dalam kajian perencanaan pengembangan pengrajin bambu di desa Parungsari, Kabupaten Karawang. Metode yang digunakan dalam penelitian ini yaitu deskriptif dan teknik pengumpulan data dilakukan dengan metode Rapid Rural Appraisal (RRA). Dari hasil analisis dan pembahasan diperoleh bahwa tingkat kemiskinan di desa Parungsari termasuk tinggi dan tingkat pendidikan yang masih rendah di karenakan biaya kehidupan yang tinggi dan kurangnya penghasilan sehingga menyebabkan terjadi kesenjangan sosial dan ekonomi.
\end{abstract}

\section{Kata Kunci}

Pemetaan Sosial, Pengrajin Bambu, Tingkat Pendidikan, Biaya Kehidupan Kesenjangan Sosial dan Ekonomi.

\begin{abstract}
Social mapping is an activity carried out to understand the social conditions of local communities. This study aims to determine and understand the condition of Parungsari village, socioeconomic conditions and as primary data in the study of bamboo craftsman development plans in Parungsari village, Karawang Regency. The method used in this research is descriptive and data collection techniques are done by the Rapid Rural Appraisal (RRA) method. From the results of the analysis and discussion it was found that the level of poverty in the village of Parungsari is high and the level of education is still low due to the high cost of living and lack of income causing social and economic disparities.
\end{abstract}

\section{Keywords}

Social Mapping, Bamboo Craftsmen, Education Level, Cost of Living Social and Economic Gaps.

\section{Pendahuluan}

Pemetaan sosial (Social Mapping) kegiatan yang dilaksanakan untuk memahami kondisi sosial masyarakat lokal. Kegiatan ini penting untuk dilakukan oleh perusahaan 


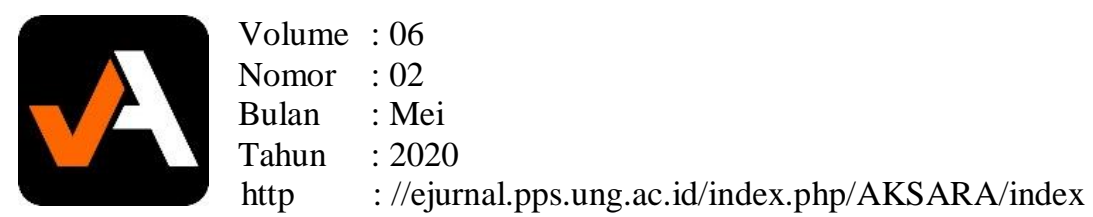

karena setiap masyarakat memiliki kondisi sosial berbeda yang akan menyebabkan masyarakat memiliki masalah dan kebutuhan yang berbeda pula. Sebagaimana tertuang dalam Buku Indikator Proper Hijau Kementerian Lingkungan Hidup, tentang Aspek pengembangan Masyarakat (Community Development) dalam Peraturan Menteri Lingkungan Hidup Republik Indonesia No 6 Tahun 2013 tentang Proper, bahwa Social Mapping memberikan gambaran menyeluruh dari lokasi yang dipetakan, meliputi aktor yang berperan dalam proses relasi sosial, jaringan sosial, kekuatan dan kepentingan masing-masing aktor dalam kehidupan masyarakat terutama dalam peningkatan kondisi kehidupan masyarakat, masalah sosial yang ada termasuk keberadaan kelompok rentan, serta potensi yang tersedia, baik alam, manusia, finansial, dan infrastruktur maupun modal sosial.

Wilayah Kabupaten Karawang secara geografis terletak antara 1070 02'-1070 40' BT dan 50 56'-60 34' LS, termasuk daerah dataran yang relatif rendah, mempunyai variasi ketinggian wilayah antara 0-1.279 meter di atas permukaan laut dengan kemiringan wilayah 0-20, 2-150, 15-400, dan diatas 400 dengan suhu rata-rata $270 \mathrm{C}$. Ketinggian yang relatif rendah $(25 \mathrm{~m} \mathrm{dpl})$ terletak pada bagian utara mencakup Kecamatan Pakisjaya, Batujaya, Tirtajaya, Pedes, Rengasdengklok, Kutawaluya, Tempuran, Cilamaya, Rawamerta, Telagasari, Lemahabang, Jatisari, Klari, Karawang, Tirtamulya, sebagian Telukjambe, Jayakerta, Majalaya, sebagian Cikampek dan sebagian Ciampel. Karawang merupakan salahsatu daerah kawasan industri terbesar di Indonesia. Sehingga pertumbuhan perekonomian di karawang cukup cepat dan merupakan peluang yang cukup bagus untuk UMKM.

Dari jumlah total 30 kecamatan di Kabupaten Karawang, masih sedikit kecamatan yang memiliki produk unggulan lokal karawang. Potensi daerah pun masih belum terlihat oleh publik. Desa Parungsari, Kecamatan Telukjambe Barat yang memiliki pengrajin bambu dan merupakan pekerjaan dan keahlian yang sudah turun temurun, masih jarang di ketahui warga masyarakat Karawang. Hal tersebut dikarenakan kurangnya pengembangan keahlian dan kurang fokusnya pemerintah terhadap potensi daerah. Kurang terjalinnya sinergitas antara pemerintahan, akademisi, komunitas, business, dan juga media. Sehingga pengembangan yang harus dilakukan secara komperhensif dan bersinergi utnuk hasil yang maksimal.

Desa Parungsari termasuk dalam kategori miskin, dengan tingkat kemiskinan KK sebanyak 864 dari 1.478 jumlah KK. Tingkat pendidikan yang masih rendah di karenakan biaya kehidupan yang tinggi, dan kurangnya penghasilan. Dalam pemetaan sosial (social mapping) didefinisikan sebagai proses penggambaran masyarakat yang sistematik serta melibatkan pengumpulan data dan informasi mengenai masyarakat termasuk di dalamnya profile dan masalah sosial yang ada pada masyarakat tersebut. Merujuk pada Netting, Kettner dan McMurtry (1993), pemetaan sosial dapat disebut juga sebagai social profiling atau "pembuatan profile suatu masyarakat".

Pemetaan sosial dapat dipandang sebagai salah satu pendekatan dalam Pengembangan Masyarakat yang oleh (Twelvetrees \& Twelvetrees, 1991) didefinisikan sebagai "the process of assisting ordinary people to improve their own communities by undertaking collective actions." Sebagai sebuah pendekatan, pemetaan sosial sangat dipengaruhi oleh ilmu penelitian sosial dan geography. Salah satu bentuk atau hasil akhir pemetaan sosial biasanya berupa suatu peta wilayah yang sudah diformat sedemikian rupa sehingga menghasilkan suatu image mengenai pemusatan karakteristik 
masyarakat atau masalah sosial, misalnya jumlah orang miskin, rumah kumuh, anak terlantar, yang ditandai dengan warna tertentu sesuai dengan tingkatan pemusatannya.

Perlu dicatat bahwa tidak ada aturan dan bahkan metoda tunggal yang secara sistematik dianggap paling unggul dalam melakukan pemetaan sosial. Prinsip utama bagi para praktisi pekerjaan sosial dalam melakukan pemetaan sosial adalah bahwa ia dapat mengumpulkan informasi sebanyak mungkin dalam suatu wilayah tertentu secara spesifik yang dapat digunakan sebagai bahan membuat suatu keputusan terbaik dalam proses pertolongannya. Mengacu pada Netting, Kettner dan McMurtry (1993:68) ada tiga alasan utama mengapa para praktisi pekerjaan sosial memerlukan sebuah pendekatan sistematik dalam melakukan pemetaan sosial. Pertama, Pandangan mengenai "manusia dalam lingkungannya" (the person-in-environment) merupakan faktor penting dalam praktek pekerjaan sosial, khususnya dalam praktek tingkat makro atau praktek pengembangan masyarakat. Masyarakat dimana seseorang tinggal sangat penting dalam menggambarkan siapa gerangan dia, masalah apa yang dihadapinya, serta sumber-sumber apa yang tersedia untuk menangani masalah tersebut. Pengembangan masyarakat tidak akan berjalan baik tanpa pemahaman mengenai pengaruh-pengaruh masyarakat tersebut.

Kedua, Pengembangan masyarakat memerlukan pemahaman mengenai sejarah dan perkembangan suatu masyarakat serta analisis mengenai status masyarakat saat ini. Tanpa pengetahuan ini, para praktisi akan mengalami hambatan dalam menerapkan nilai-nilai, sikap-sikap dan tradisi-tradisi pekerjaan sosial maupun dalam memelihara kemapanan dan mengupayakan perubahan.

Ketiga, Masyarakat secara konstan berubah. Individu-individu dan kelompokkelompok begerak kedalam perubahan kekuasaan, struktur ekonomi, sumber pendanaan dan peranan penduduk. Pemetaan sosial dapat membantu dalam memahami dan menginterpretasikan perubahan-perubahan tersebut.

\section{METODE PENELITIAN}

Penelitian ini termasuk penelitian deskriptif karena dalam penelitian ini mendeskripsikan data pemetaan sosial masyarakat dan pengrajin bambu di desa Parungsari yang akan menerima CSR dalam bentuk pengembangan UMKM bambu.

Pendekatan pemetaan sosial, metode dan teknik pemetaan sosial yang akan dibahas pada makalah ini meliputi survey formal, pemantauan cepat (rapid appraisal) dan metode partisipatoris (participatory method) (LCC, 1977; Suharto, 1997; World Bank, 2002). Dalam wacana penelitian sosial, metode survey formal termasuk dalam pendekatan penelitian makro-kuantitatif, sedangkan metode pemantauan cepat dan partisipatoris termasuk dalam penelitian mikro-kualitatif (Suharto, 1997).

Survey Formal, dapat digunakan untuk mengumpulkan informasi standar dari sampel orang atau rumahtangga yang diseleksi secara hati-hati. Survey biasanya mengumpulkan informasi yang dapat dibandingkan mengenai sejumlah orang yang relatif banyak pada kelompok sasaran tertentu. Beberapa metode survey formal antaralain: 1) Survey Rumah tangga Beragam-Topik (Multi-Topic Household Survey). Metode ini sering disebut sebagai Survey Pengukuran Standar Hidup atau Living Standards Measurement Survey (LSMS). Survey ini merupakan suatu cara pengumpulan data mengenai berbagai aspek standar hidup secara terintegrasi, seperti pengeluaran, komposisi rumah tangga, pendidikan, kesehatan, pekerjaan, fertilitas, gizi, 


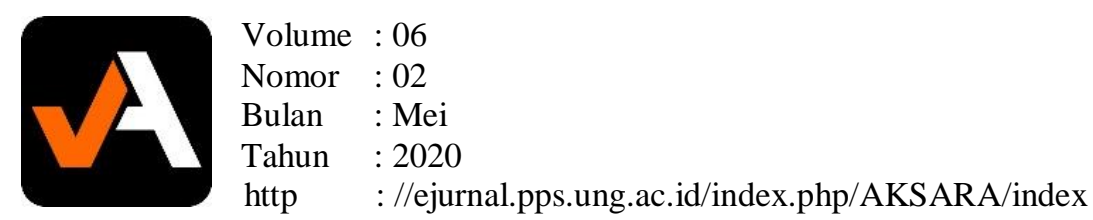

tabungan, kegiatan pertanian dan sumber-sumber pendapatan lainnya. 2) Kuesioner Indikator Kesejahteraan Inti (Core Welfare Indicators Questionnaire atau CWIQ). Metode ini merupakan sebuah survey rumah tangga yang meneliti perubahanperubahan indikator sosial, seperti akses, penggunaan, dan kepuasan terhadap pelayanan sosial dan ekonomi. Metode ini meupakan alat yang cepat dan effektif untuk mengetahui rancangan kegiatan pelayanan bagi orang-orang miskin. Jika alat ini diulang setiap tahun, maka ia dapat digunakan untuk memonitor keberhasilan suatu kegiatan. Sebuah hasil awal dari survey ini umumnya dapat diperoleh dalam waktu 30 hari. 3) Survey Kepuasan Klien (Client Satisfaction Survey). Survey ini digunakan untuk meneliti efektifitas atau keberhasilan pelayanan pemerintah berdasarkan pengalaman atau aspirasi klien (penerima pelayanan). Metode yang sering disebut sebagai service delivery survey ini mencakup penelitian mengenai hambatan-hambatan yang dihadapi penerima pelayanan dalam memperoleh pelayanan publik, pandangan mereka mengenai kualitas pelayanan, serta kepekaan petugas-petugas pemerintah. 4) Kartu Laporan Penduduk (Citizen Report Cards). Teknik ini sering digunakan oleh Lembaga Swadaya Masyarakat (LSM). Mirip dengan Survey Kepuasan Klien, penelitian difokuskan pada tingkat korupsi yang ditemukan oleh penduduk biasa. Penemuan ini kemudian dipublikasikan secara luas dan dipetakan sesuai dengan tingkat dan wilayah geografis. 5) Laporan Statistik. Pekerja sosial dapat pula melakukan pemetaan sosial berdasarkan laporan statistik yang sudah ada. Laporan statistik mengenai permasalahan sosial seperti jumlah orang miskin, desa tertinggal, status gizi, tingkat buta huruf, dan lain-lain. biasanya dilakukan dan dipublikasikan oleh Badan Pusat Statistik (BPS) berdasarkan data sensus.

Metode Rapid Rural Appraisal, Metode ini digunakan untuk mengumpulkan informasi secara akurat dalam waktu yang terbatas. Metode RRA pada dasarnya merupakan proses belajar intensif untuk memahami kondisi masyarakat, dilakukan berulang-ulang dan cepat, menggunakan metode, cara dan pemilihan teknik tertentu untuk meningkatkan pemahaman terhadap kondisi masyarakat. Metode tersebut dipusatkan pada pemahaman tingkat komunitas lokal yang digabungkan dengan pengetahuan ilmiah. 3 (tiga) konsep dasar metode RRA adalah a). perspektif system, b). triangulasi dari pengumpulan data, c). pengumpulan data dan analisis secara berulang-ulang (iterative).

Metode ini merupakan cara yang cepat dan murah untuk mengumpulkan informasi mengenai pandangan dan masukan dari populasi sasaran dan stakeholders lainnya mengenai kondisi geografis dan sosial-ekonomi. Metode RRA meliputi: 1) Wawancara Informan Kunci (Key Informant Interview). Wawancara ini terdiri serangkaian pertanyaan terbuka yang dilakukan terhadap individu-individu tertentu yang sudah diseleksi karena dianggap memiliki pengetahuan dan pengalaman mengenai topik atau keadaan di wilayahnya. Wawancara bersifat kualitatif, mendalam dan semiterstruktur. 2) Diskusi Kelompok Fokus (Focus Group Discussion). Disikusi kelompok dapat melibatkan 8 sampai 12 anggota yang telah dipilih berdasarkan kesamaan latar belakang. Perserta diskusi bisa para penerima pelayanan, penyandang masalah kesejahteraan sosial (PMKS), atau para ketua Rukun Tetangga. Fasilitator menggunakan petunjuk diskusi, mencatat proses diskusi dan kemudian memberikan komentar mengenai hasil pengamatannya. 3) Wawancara Kelompok Masyarakat (Community Group Interview). Wawancara difasilitasi oleh serangkaian pertanyaan 
yang diajukan kepada semua anggota masyarakat dalam suatu pertemuan terbuka. Pewawancara melakukan wawancara secara hati-hati berdasarkan pedoman wawancara yang sudah disiapkan sebelumnya. 4) Pengamatan Langsung (Direct Observation). Melakukan kunjungan lapangan atau pengamatan langsung terhadap masyarakat setempat. Data yang dikumpulkan dapat berupa informasi mengenai kondisi geografis, sosial-ekonomi, sumber-sumber yang tersedia, kegiatan program yang sedang berlangsung, interaksi sosial, dll. 5) Survey Kecil (Mini-Survey). Penerapan kuesioner terstruktur (daftar pertanyaan tertutup) terhadap sejumlah kecil sample (antara 50-75 orang). Pemilihan responden dapat menggunakan teknik acak (random sampling) ataupun sampel bertujuan (purposive sampling). Wawancara dilakukan pada lokasilokasi survey yang terbatas seperti sekitar klinik, sekolah, balai desa.

Teknik pengumpulan data dilakukan dengan metode Rapid Rural Appraisal (RRA), yaitu suatu pendekatan partisipatif untuk mendapatkan data/informasi dan penilaian (assesment) secara umum di lapangan dalam waktu yang relatif pendek. Kelebihan pendekatan ini adalah penelitian bisa mencakup daerah yang lebih luas dalam waktu relatif singkat untuk mendapatkan informasi yang luas secara umum. Pengumpulan informasi dan data dilakukan secara fleksibel, tidak terikat secara kaku dengan kuesioner.

Dalam metode RRA ini informasi yang dikumpulkan terbatas pada data yang dibutuhkan sesuai dengan tujuan penelitian, namun dilakukan dengan lebih mendalam dengan menelusuri sumbernya sehingga didapatkan informasi yang lengkap tentang sesuatu hal.

Pengumpulan data dilakukan dengan teknik angket, wawancara, dan studi dokumenter. Angket dimaksudkan untuk mengumpulkan data primer tentang aktivitas pengrajin dalam produksi sekaligus pemasaran produk, dan persepsi/pandangan pengrajin bambu tentang renaca developing. Sedangkan studi dokumentasi dimaksudkan untuk menjaring data yang tidak dapat dijaring melalui angket dan studi dokumentasi. Data sekunder di ambil dari data yangdiperoleh dari pemerintah desa setempat.

Dalam penyusunan angket digunakan model dari Rensis Likert, yaitu dengan option: masing-masing diberikan derajat yang merentang mulai dari 5 untuk Sangat Kuat (SK) / Sangat Baik (SB) / Sangat Setuju (SS), rentang 4 Kuat (K) / Setuju (S) / Baik (B), rentang 3 untuk Cukup Kuat (CK) / Cukup Setuju (CS) / Cukup Baik (CB), rentang 2 untuk Tidak Kuat (TK) / Tidak Setuju (TS) / Tidak Baik (TB), dan rentang 1 Sangat tidak Kuat (STK) / Sangat Tidak Setuju (STS) / Sangat Tidak Baik (STB). Data yang diperoleh meliputi : 1) Profil desa meliputi : a. Geografis, meliputi lokasi masyarakat, lokasi-lokasi fasilitas, akses jalan, penggunaan lahan, dan aspek geografis lainnya. b. Demografi, statistik mengenai komposisi penduduk (jenis kelamin, ketenagakerjaan, tingkat kemiskinan, tingkat pendidikan, tingkat kesejahteraan, dsb). c. Sosial ekonomi, matapencaharian, budaya, norma dan nilai masyarakat,struktur masyarakat, hubungan sosial, mobilitas sosial, kepemimpinan masyarakat, adat istiadat dan kebiasaan. 2. Pemetaan Jaringan Sosial mencakup : a. Hubungan antar aktor, baik individu maupun institusi beserta sifat hubungannya, baik positif maupun negatif yang dituangkan dalam bentuk skema. b. Forum-forum yang digunakan masyarakat untuk membahas kepentingan public. c. Potensi yang berada dalam masyarakat yang mungkin bisa dikembangkan: potensi alam, potensi 


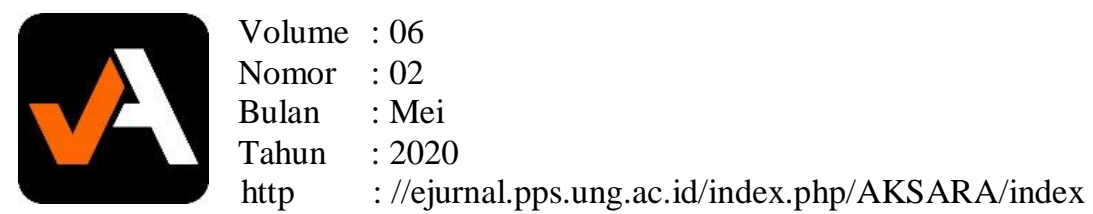

sumberdaya manusia, potensi finansial, potensi fisik/infrastruktur, potensi modal sosial. d. Masalah-masalah sosial yang menjadi kendala atau sering muncul sehingga menjadi penghambat berkembangnya masyarakat. 3. Pemetaan Potensi Skill Pengrajin Bambu : a. Keahlian / skill yang dimiliki tiap perorangan pengrajin bambu. b. Produk yang biasa dibuat dengan bahan dasar bambu. c. Pendapatan yang diperoleh dalam menjual produk bambu. d. Pemasaran adalah upaya pemasaran yang dilakukan selama ini.

\section{HASIL DAN PEMBAHASAN}

Desa Parungsari merupakan salah satu desa yang berada di wilayah administrative Kecamatan Telukjambe Barat Kabupaten Karawang. Jumlah Kepala Keluarga sebanyak 1.278, dengan jumlah kepala keluarga miskin sebanyak 864 . Lebih dari 50\% jumlah kepala keluarga miskin, sehingga desa parungsari termasuk dalam kategori dengan taraf kemiskinan.

Penduduk yang tidak sekolah sebanyak 363 orang, tamat SD sebanyak 489 orang, tamatan SMP sebanyak 239 orang, tamatan SMA 287 orang, dan tamatan sarjana sebanyak 44 orang. Masyarakat yang melaksanakan pendidikan 9 tahun masih sangatlah minim.

Dengan mata pencaharian dominan sebagai petani ataupun penggarap sebanyak 349 orang dan jumlah pengrajin bambu sebanyak 47orang, bahkan pengrajin bambu pun sebagai penggarap tani ataupun berternak. Sehingga menjadi pengrajin bambu bukanlah perkerjaan pokok. yaitu :

Adapun aktor-aktor di desa Parungsari, yang dapat mempengaruhi aktivitas warga

1. Jumlah pengurus RT 9 orang,

2. Jumlah pengurus RW 2 orang,

3. Jumlah pengurus aktor desa 2 orang,

4. Jumlah tokoh agama 13 orang,

5. Jumlah tokoh karangtaruna 14 orang,

6. Jumlah pengrajin bambu 47 orang

Aktor inilah yang mempengaruhi dalam kondisi sosial dan memiliki peran terhadap pertumbuhan ekonomi dan sosial pada warga di desa Parungsari, kecamatan Telukjambe Barat.

Jumlah Pengrajin bambu di desa parungsari sebanyak 47 orang, yang terdata dari desa. Menjadi pengrajin bambu bukanlah matapencaharian utama, sebagian besar dari mereka selain menjadi pengrajin bambu juga sebagai petani ataupun peternak. Sehingga menjual bambu dilakukan apabila musim panen telah berlalu, atau dilakukan jika ada pesanan.

Dari 47orang pengrajin, kami mendapatkan fakta orang-orang yang konsisten dalam bisnis kerajinan bambu berkisar 29 orang pengrajin aktif. Berikut data yang berhasil di himpun dari 19 orang pengrajin bamboo yang kami temui, dikarenakan masih musim panen di sawah, maka sebagian besar dari mereka menghabiskan waktu untuk bertani. 
Tabel 1.1

Data Responden Pengrajin Bambu di Desa Parungsari

\begin{tabular}{|c|c|c|c|c|c|c|}
\hline No & Nama & $\begin{array}{c}\text { Usia } \\
\text { (tahun) }\end{array}$ & Keahlian & Jenis Produk & Pemasaran & Penghasilan \\
\hline 1 & Anam & 52 & $\begin{array}{l}\text { Memotong, } \\
\text { mengukur, memahat, } \\
\text { tali temali }\end{array}$ & Bilik, Kursi & $\begin{array}{c}\text { Jual } \\
\text { keliling }\end{array}$ & $\begin{array}{c}\text { Rp. } \\
\text { 1.000.000,- }\end{array}$ \\
\hline 2 & Itam & 75 & $\begin{array}{l}\text { Memotong, } \\
\text { mengukur, memahat, } \\
\text { tali temali }\end{array}$ & $\begin{array}{l}\text { Kursi tamu set, } \\
\text { Kursi santai }\end{array}$ & $\begin{array}{c}\text { Keliling } \\
\text { dan Online }\end{array}$ & $\begin{array}{c}\text { Rp. } \\
700.000,-\end{array}$ \\
\hline 3 & Satam & 46 & $\begin{array}{l}\text { Memotong, } \\
\text { mengukur, memahat, } \\
\text { tali temali, dan } \\
\text { menganyam }\end{array}$ & $\begin{array}{l}\text { Pagar, Bangku } \\
\text { dan Bilik }\end{array}$ & Pesanan & $\begin{array}{c}\text { Rp. } \\
\text { 2.160.000,- }\end{array}$ \\
\hline 4 & Sakim & 56 & $\begin{array}{l}\text { Memotong, } \\
\text { mengukur, memahat, } \\
\text { tali temali }\end{array}$ & Kursi duduk & Pengepul & $\begin{array}{c}\text { Rp. } \\
\text { 3.600.000,-- }\end{array}$ \\
\hline 5 & Madi & 51 & $\begin{array}{l}\text { Memotong, } \\
\text { mengukur, memahat, } \\
\text { tali temali }\end{array}$ & $\begin{array}{l}\text { Pagar, Bangku } \\
\text { dan Kursi }\end{array}$ & $\begin{array}{c}\text { Keliling } \\
\text { dan Online }\end{array}$ & $\begin{array}{c}\text { Rp. } \\
1.500 .000,-\end{array}$ \\
\hline 6 & Yana & 49 & $\begin{array}{l}\text { Memotong, } \\
\text { mengukur, memahat, } \\
\text { tali temali }\end{array}$ & $\begin{array}{l}\text { Berbagai Kursi } \\
\text { dan Kerai }\end{array}$ & $\begin{array}{c}\text { Keliling } \\
\text { dan Online }\end{array}$ & $\begin{array}{c}\text { Rp. } \\
\text { 4.000.000,- }\end{array}$ \\
\hline 7 & Dudung & 53 & $\begin{array}{l}\text { Memotong, } \\
\text { mengukur, memahat, } \\
\text { tali temali }\end{array}$ & Kursi dan Balai & Keliling & $\begin{array}{c}\text { Rp. } \\
\text { 4.000.000,- }\end{array}$ \\
\hline 8 & Eman & 39 & $\begin{array}{l}\text { Memotong, } \\
\text { mengukur, memahat, } \\
\text { tali temali }\end{array}$ & $\begin{array}{l}\text { Kursi tamu set } \\
\text { dan Balai }\end{array}$ & $\begin{array}{c}\text { Keliling } \\
\text { dan Online }\end{array}$ & $\begin{array}{c}\text { Rp. } \\
1.000 .000,- \\
\text { s/d Rp. } \\
2.000 .000,-\end{array}$ \\
\hline 9 & Atem & 40 & $\begin{array}{l}\text { Memotong, } \\
\text { mengukur, memahat, } \\
\text { tali temali }\end{array}$ & $\begin{array}{l}\text { Kursi tamu dan } \\
\text { Kursi Santai }\end{array}$ & $\begin{array}{l}\text { Pesanan } \\
\text { dan } \\
\text { Pengepul }\end{array}$ & $\begin{array}{l}\text { Rp. } \\
\text { 400.000,- }\end{array}$ \\
\hline 10 & Cawin & 52 & $\begin{array}{l}\text { Memotong, } \\
\text { mengukur, memahat, } \\
\text { tali temali }\end{array}$ & $\begin{array}{l}\text { Set kursi dan } \\
\text { Balai }\end{array}$ & Keliling & $\begin{array}{c}\text { Rp. } \\
1.000 .000,-\end{array}$ \\
\hline 11 & Darmin & 55 & $\begin{array}{l}\text { Memotong, } \\
\text { mengukur, memahat, } \\
\text { tali temali dan } \\
\text { menganyam }\end{array}$ & $\begin{array}{l}\text { Pagar, Bangku } \\
\text { dan Bilik }\end{array}$ & Pesanan & $\begin{array}{c}\text { Rp. } \\
1.000 .000,-\end{array}$ \\
\hline 12 & Carim & 53 & $\begin{array}{l}\text { Memotong, } \\
\text { mengukur, memahat, } \\
\text { tali temali dan } \\
\text { menganyam }\end{array}$ & Kursi malas & Pengepul & $\begin{array}{c}\text { Rp. } \\
\text { 5.800.000,- }\end{array}$ \\
\hline 13 & Taman & 49 & $\begin{array}{l}\text { Memotong, } \\
\text { mengukur, memahat, } \\
\text { tali temali dan } \\
\text { menganyam }\end{array}$ & $\begin{array}{l}\text { Kursi malas dan } \\
\text { ilik Meja }\end{array}$ & Keliling & $\begin{array}{c}\text { Rp. } \\
2.000 .000,-\end{array}$ \\
\hline
\end{tabular}


http : //ejurnal.pps.ung.ac.id/index.php/AKSARA/index

\begin{tabular}{|c|c|c|c|c|c|c|}
\hline 14 & Sakim & 53 & $\begin{array}{l}\text { Memotong, } \\
\text { mengukur, memahat, } \\
\text { tali temali, }\end{array}$ & $\begin{array}{l}\text { Kursi malas dan } \\
\text { Kursi Set }\end{array}$ & Pengepul & $\begin{array}{c}\text { Rp. } \\
2.800 .000,-\end{array}$ \\
\hline 15 & Tanu & 50 & $\begin{array}{l}\text { Memotong, } \\
\text { mengukur, memahat, } \\
\text { tali temali, }\end{array}$ & $\begin{array}{l}\text { Kursi malas dan } \\
\text { Kursi Set }\end{array}$ & Keliling & $\begin{array}{c}\text { Rp. } \\
2.500 .000,-\end{array}$ \\
\hline 16 & Itam & 50 & $\begin{array}{l}\text { Memotong, } \\
\text { mengukur, memahat, } \\
\text { tali temali, }\end{array}$ & $\begin{array}{l}\text { Kursi malas dan } \\
\text { Kursi Set }\end{array}$ & Keliling & $\begin{array}{c}\text { Rp. } \\
2.500 .000,-\end{array}$ \\
\hline 17 & Ating & 56 & $\begin{array}{l}\text { Memotong, } \\
\text { mengukur, memahat, } \\
\text { tali temali, }\end{array}$ & Kursi malas & Pengepul & $\begin{array}{c}\text { Rp. } \\
1.800 .000,-\end{array}$ \\
\hline 18 & Sawita & 21 & $\begin{array}{l}\text { Memotong dan } \\
\text { mengukur }\end{array}$ & $\begin{array}{l}\text { Kursi malas, } \\
\text { kursi tamu set }\end{array}$ & $\begin{array}{l}\text { Pengepul } \\
\text { dan Online }\end{array}$ & $\begin{array}{c}\text { Rp. } \\
\text { 5.000.000,- } \\
\text { s/d Rp. } \\
\text { 16.000.000,- }\end{array}$ \\
\hline 19 & Darim & 43 & $\begin{array}{l}\text { Memotong, } \\
\text { mengukur, memahat, } \\
\text { tali temali, dan } \\
\text { menganyam }\end{array}$ & $\begin{array}{l}\text { Kursi malas, } \\
\text { kursi tamu set, }\end{array}$ & $\begin{array}{c}\text { Keliling } \\
\text { dan Online }\end{array}$ & $\begin{array}{c}\text { Rp. } \\
2.000 .000,-\end{array}$ \\
\hline
\end{tabular}

Sumber : interview 2019

Dari data dan informasi yang berhasil kami himpun, sebagian besar pengrajin juga bertindak sebagai pengepull barang jadi, yang artinya pengepull lebih banyak beraktivitas di marketing melalui offline (pesanan), online (medsos), dan juga E-commerce. Pada salah satu pengepull yang bernama Bpk.Sawita dapat merasakan keuntungan yang signifikan dari produk hasil karya pengrajin bambu di Parungsari, dengan cara penjualan online dan memanfaatkan e-commerce. Penghasilan yang di dapatkan berkisar Rp. 5.000.000,- samapai dengan Rp. 16.000.000,- perbulan.

Dari hasil interview yang dilakukan terhadap pengrajin bambu, dari segi sosial ekonomi, dengan variabel sumberdaya, kondisi lahan produktif yang dapat dimanfaatkan, karakteristik/sikap, penghasilan dan biaya hidup. Dapat dilihat dari beberapa variabel tersebut, bahwa pengrajin bambu memiliki sikap dan pemikiran terbuka dan siap untuk menerima perubahan untuk hidup lebih baik (improvement). Sehingga pengrajin bambu sangat mengharapkan pengembangan keahlian dan perluasan jaringan pemasaran, dan juga sentuhan teknologi berupa alat-alat. 
Tabel 4.2

Data Responden Pengrajin Bambu di Desa Parungsari

\begin{tabular}{|c|c|c|c|c|c|c|c|c|}
\hline \multirow{2}{*}{ Variabel } & \multirow{2}{*}{\multicolumn{2}{|c|}{ Indikator }} & \multicolumn{5}{|c|}{ Frekuensi } & \multirow{2}{*}{ Kriteria } \\
\hline & & & 1 & 2 & 3 & 4 & 5 & \\
\hline \multirow{2}{*}{ Sumberdaya } & 1 & $\begin{array}{l}\text { Apakah saudara setuju jika } \\
\text { kompetensi pengrajin bambu } \\
\text { ditingkatkan? }\end{array}$ & $6 \%$ & $12 \%$ & $5 \%$ & $24 \%$ & $53 \%$ & $\begin{array}{l}\text { Sangat } \\
\text { Setuju }\end{array}$ \\
\hline & 2 & $\begin{array}{l}\text { Apakah saudara mendukung jika } \\
\text { ada program pengembangan } \\
\text { pengrajin bambu? }\end{array}$ & $6 \%$ & $0 \%$ & $0 \%$ & $29 \%$ & $65 \%$ & $\begin{array}{l}\text { Sangat } \\
\text { Setuju }\end{array}$ \\
\hline \multirow{2}{*}{$\begin{array}{c}\text { Kondisi } \\
\text { Lahan } \\
\text { Produktif } \\
\text { Yang Dapat } \\
\text { Dimanfaatkan }\end{array}$} & 3 & $\begin{array}{l}\text { Terdapat kolam/empang produktif } \\
\text { yang belum dimanfaatkan }\end{array}$ & $29 \%$ & $18 \%$ & $12 \%$ & $35 \%$ & $6 \%$ & Setuju \\
\hline & 4 & $\begin{array}{l}\text { Apakah saudara setuju jika sawah, } \\
\text { kolam/empang dan lahan non } \\
\text { produktif diberdayagunakan? }\end{array}$ & $29 \%$ & $0 \%$ & $12 \%$ & $35 \%$ & $24 \%$ & Setuju \\
\hline \multirow{8}{*}{$\begin{array}{l}\text { Karakteristik/ } \\
\text { Sikap }\end{array}$} & 5 & Aparat desa yang kooperatif & $6 \%$ & $24 \%$ & $12 \%$ & $46 \%$ & $12 \%$ & Setuju \\
\hline & 6 & Ketua RW yang kooperatif & $6 \%$ & $18 \%$ & $29 \%$ & $35 \%$ & $12 \%$ & Setuju \\
\hline & 7 & Ketua RT yang kooperatif & $6 \%$ & $18 \%$ & $18 \%$ & $29 \%$ & $29 \%$ & Setuju \\
\hline & 8 & Warga yang ramah dan kooperatif & $0 \%$ & $0 \%$ & $18 \%$ & $47 \%$ & $35 \%$ & Setuju \\
\hline & 9 & $\begin{array}{l}\text { Warga yang sangat siap menerima } \\
\text { perubahan }\end{array}$ & $0 \%$ & $0 \%$ & $6 \%$ & $35 \%$ & $59 \%$ & $\begin{array}{l}\text { Sangat } \\
\text { Setuju }\end{array}$ \\
\hline & 10 & $\begin{array}{l}\text { Memiliki budaya organisasi yang } \\
\text { positif }\end{array}$ & $0 \%$ & $12 \%$ & $12 \%$ & $52 \%$ & $24 \%$ & Setuju \\
\hline & 11 & $\begin{array}{l}\text { Memiliki keterbukaan pemikiran } \\
\text { dalam menerima perubahan }\end{array}$ & $0 \%$ & $12 \%$ & $18 \%$ & $46 \%$ & $24 \%$ & Setuju \\
\hline & 12 & $\begin{array}{l}\text { Apakah saudara setuju dalam } \\
\text { menghadapi perubahan kearah yang } \\
\text { lebih baik (improvement)? }\end{array}$ & $0 \%$ & $0 \%$ & $12 \%$ & $35 \%$ & $53 \%$ & $\begin{array}{l}\text { Sangat } \\
\text { Setuju }\end{array}$ \\
\hline \multirow{4}{*}{$\begin{array}{l}\text { Penghasilan } \\
\text { dan Biaya } \\
\text { Hidup }\end{array}$} & \multirow{2}{*}{13} & \multirow{2}{*}{$\begin{array}{l}\text { Berapa jumlah penghasilan } \\
\text { perbulan? }\end{array}$} & $<1 \mathrm{jt}$ & $1 \mathrm{jt}-3 \mathrm{jt}$ & $3 \mathrm{jt}-5 \mathrm{jt}$ & $5 \mathrm{jt}-8 \mathrm{jt}$ & $8 \mathrm{jt}-10 \mathrm{jt}$ & \\
\hline & & & $12 \%$ & $71 \%$ & $18 \%$ & $0 \%$ & $0 \%$ & \\
\hline & \multirow{2}{*}{14} & \multirow{2}{*}{$\begin{array}{l}\text { Berapa jumlah biaya hidup } \\
\text { perbulan? }\end{array}$} & $<1 \mathrm{jt}$ & $1 \mathrm{jt}-3 \mathrm{jt}$ & $3 \mathrm{jt}-5 \mathrm{jt}$ & $5 \mathrm{jt}-8 \mathrm{jt}$ & $8 \mathrm{jt}-10 \mathrm{jt}$ & \\
\hline & & & $12 \%$ & $76 \%$ & $12 \%$ & $0 \%$ & $0 \%$ & \\
\hline
\end{tabular}

Sumber : data diolah 2019

Pada variabel sumberdaya dapat terlihat motivasi yang cukup besar untuk menerima pengembangan ilmu dan skill. Tetapi bahan baku berkualitas yang agak sulit di dapatkan. Selama ini pengrajin menggunakan bambu/bahan baku yang berasal dari lokal karawang, yaitu loji. Sedangkan jika dibandingkan dengan hasil benchmarking di brajan, bahanbaku yang digunakan pengrajin brajan.

Pada variabel kondisi lahan produktif yang dapat dimanfaatkan, pengrajin setuju jika lahan dapat dimanfaatkan. Hasil interview dengan kepala desa, terdapat lahan milik desa yang dapat dipergunakan untuk workshop.

Karakteristik dan sikap pengrajin cukup baik, dan masih bekerja secara induvidual. Hal tersebut dikarenakan belum terbentuknya komunitas pengrajin bambu. Sejauh ini silaturahmi yang terjalin antar pengrajin cukup baik. Hubungan antar aktor di desa cukup baik, para pejabat di desa pun kooperatif, sehingga dapat mempermudah urusan warga dan mudah diajak kerjasama. Budaya organisasi yang ada di desa sudah terbentuk dengan baik. Sudah terdapat beberapa peranan dalam proses produksi bambu, misal sudah ada pengepull bahanbaku bambu, para pengrajin yang memproduksi, dan pengepull produk jadi (pemasaran). Proses produksi dilakukan dengan metode dan alatalat tradisional yang masih manual. Pengrajin memproduksi secara individual, tiap pengrajin dapat menghasilkan produk finishgood masing-masing. 


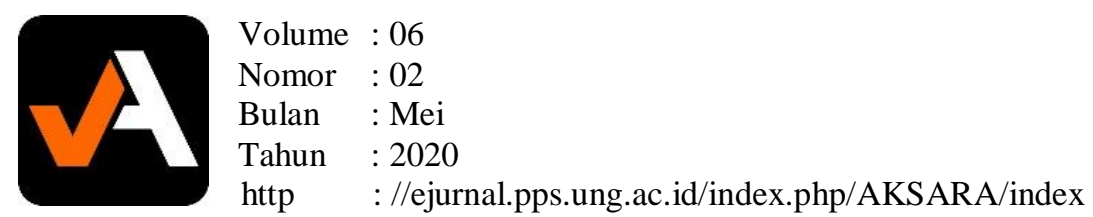

Dari tingkat penghasilan para pengrajin masih belum signifikan dan belum bisa menjadi matapencaharian andalan. Sehingga pengrajin bambu sebagian besar juga masih bekerja sebagai penggarap tani / petani, atau peternak.

\section{SIMPULAN}

Berdasarkan hasil pembahasan di bab sebelumnya mengenai pemetaan social di desa Parungsari dapat diambil kesimpulan sebagai berikut:

1. Tingkat kemiskinan pada desa Parungsari masih 50\% dari jumlah KK yang ada, hal ini menyebabkan terjadi kesenjangan sosial dan ekonomi. Sehingga mindset yang terbentuk pada tiap pengrajin adalah bagaimana menghasilkan atau dapat menjual produk bambu tersebut secara individu, dan dapat memenuhi kebutuhan hidup. Walaupun tak jarang dalam sehari mereka tidak dapat menjual produknya sama sekali. Sehingga begitu tampak egosentris yang sangat kental antar pengrajin. Hampir semua pengrajin memiliki profesi lain antara lain sebagai penggarap pertanian, petani, dan berternak.

2. Dari jumlah pengrajin bambu 47orang, yang masih aktif dan konsisten terdapat sekitar 29 orang. Belum terbentuknya kelompok atau komunitas pengrajin bambu pada desa tersebut. Belum terjalinnya kerjasama yang continue dan berkesinambungan antar pengrajin. Tiap pengrajin dapat membuat dan menjual produknya masing-masing. Metode kerja masih individual dan menggunakan peralatan manual dan tradisional. Pemasaran masih di lakukan dengan cara Offline (berkeliling dengan motor), online (Sosmed), E-commerce (Tokopedia, dll...).

3. Ada beberapa tokoh pengrajin bambu yang dapat di andalkan dan menjadi pioneer dalam melakukan bisnis bambu. Karena beberapa pengepull produk bambu menunjukkan demand akan produk cukup baik. Para pengepull / agen produk bambu tersebut sudah melakukan penjualan dengan online dan memanfaatkan e-commerce. Dari hal tersebut dapat dilihat dari tingkat penjualan yang cukup baik. Penjualan secara offline dilakukan dengan cara berkeliling menggunakan motor, dan belum adanya showroom di lokasi strategis.

\section{DAFTAR PUSTAKA}

Hikmat, H. (2001). Strategi pemberdayaan masyarakat. Humaniora Utama Press.

LCC (League of California Cities) (1977), "Problem Analysis: Data Collection Technique", dalam Gilbert, Neil dan Harry Specht, Planning for Social Welfare: Issues, Models and Tasks, New Jersey: Prentice-Hall, hal. 311-323.

Netting, F. E. Petter M. Kettner dan Steven L. McMurtry.(1993). Social Work Practice. Pemerintah Desa Parungsari, 2019. Profile sosial dan ekonomi, Rencana Kerja Tahunan Desa (RKP Desa) Parungsari, Kecamatan Telukjambe Barat, Kabupaten Karawang. Peraturan Menteri Lingkungan Hidup Republik Indonesia, 2013. Nomor 06 Tahun 2013

Tentang Program Penilaian Peringkat Kinerja Perusahaan Dalam Pengelolaan Lingkungan Hidup

Suharto, E. (1997). Pembangunan, Kebijakan Sosial dan Pekerjaan Sosial: Spektrum Pemikiran. Bandung: Lembaga Studi Pembangunan STKS (LSP-STKS).

Twelvetrees, A., \& Twelvetrees, A. (1991). What is Community Work? In Community Work. https://doi.org/10.1007/978-1-349-21262-0_1

Warren, R. L. (1978). The community in America. Rand McNally College Pub. Co. 